\title{
Article \\ A New Strategic Marketing Management Model for the Specificities of E-Commerce in the Supply Chain
}

\author{
Balázs Gyenge ${ }^{1}\left(\mathbb{D}\right.$, Zoltán Máté $^{2}$, Imre Vida $^{3}$, Yuriy Bilan ${ }^{4}$ and László Vasa ${ }^{5, * \mathbb{C}}$ \\ 1 Department of Operation Management and Logistics, Institute of Supply Chain Management, \\ Marketing and Tourism, Faculty of Economy and Social Sciences, Szent István University, \\ 2100 Gödölló, Hungary; gyenge.balazs@szie.hu \\ 2 Department of Marketing, Faculty of Foreign Trade, Budapest Business School, 1165 Budapest, Hungary; \\ mate.zoltan@uni-bge.hu \\ 3 Faculty of Economy and Social Sciences, Szent István University, 1165 Budapest, Hungary; \\ info@vidaimre.com \\ 4 Institute of Management, University of Social Sciences, 90-113 Lodz, Poland; y.bilan@prz.edu.pl \\ 5 Management Campus, Széchenyi István University, 9026 Győr, Hungary \\ * Correspondence: laszlo.vasa@ifat.hu; Tel.: +36-203-337-833
}

check for updates

Citation: Gyenge, B.; Máté, Z.; Vida, I.; Bilan, Y.; Vasa, L. A New Strategic Marketing Management Model for the Specificities of E-Commerce in the Supply Chain. J. Theor. Appl. Electron. Commer. Res. 2021, 16, 1136-1149. https://doi.org/10.3390/jtaer16040064

Academic Editor: Dan-Cristian Dabija

Received: 1 March 2021

Accepted: 22 March 2021

Published: 25 March 2021

Publisher's Note: MDPI stays neutral with regard to jurisdictional claims in published maps and institutional affiliations.

Copyright: (c) 2021 by the authors. Licensee MDPI, Basel, Switzerland. This article is an open access article distributed under the terms and conditions of the Creative Commons Attribution (CC BY) license (https:/ / creativecommons.org/licenses/by/ $4.0 /)$.

\begin{abstract}
The study seeks to answer the question of what strategic directions and opportunities we have for business in the midst of the info-communication changes of our time. In this research, we compare the results of non-representative primary research (cluster analysis and discriminant analysis) with the factors and latest methods of e-commerce or even mobile commerce and traditional commerce and their main differences. Based on the four clusters examined, we develop a new strategic model for practice with suggestions which can be used by small and medium-sized enterprises (SMEs) and which they can incorporate directly into their business models. Starting point of our hypothesis was that in order to develop an effective and delivered communication, a market needs to be targeted and at least four different clusters should be formulated.
\end{abstract}

Keywords: business development; online marketing; e-commerce; effective communication; social media; social networking; m-commerce

\section{Introduction}

Marketing professionals and advertisers are increasingly using e-commerce, $\mathrm{m}$-commerce, or social media and enthusiastically using different platforms, but the effectiveness of these tools is still vague. This is not because the evaluation of these electronic tools is inaccurate or not as good as evaluation through social media monitoring tools that provide quantitative indicators such as, sharing, comment, click-through, view, number of followers, etc. One of the main problems in integrating these tools is that nowadays, different customer behaviors are becoming much more significant. Academic research also tends to focus on content or context (i.e., platform or tools and types of social media) [1] but we postulate that each of them is determined by different groups of media users and their media usage habits. The novelty of our research and the paper is the emphasis on the importance of differentiating in communication according to smaller user groups, as customer behavior are becoming more significant and should resist the temptation to use mass communication with these internet tools. This study examines how we can set up as few customer groups as possible to develop different strategies for them and their engagement with social media platforms. Theoretically, we will elaborate and examine the relevance of resulting clusters and develop a new two-dimensional action matrix with recommendations as a contribution to practice.

\section{Literature Review}

Let us start our short introduction into the topic with some interpretation or viewpoints as the fundamental basis of marketing logistics. For the sake of clarity, let us take a shot look 
at the following conceptual boundaries that will help us to perform better analysis. As each era has its own marketing concept, Gamble et al. [2] we would like to focus on what is the anatomy of marketing compared to scientific definitions. Marketing is a corporate activity that analyses the market to meet the needs of customers or users, defines the desired products and services, considering the value dimensions, defines its target audience (because what is made for everyone is actually made for nobody) and then introduces them with each other (product with customer, customer with product), sets the sales price with full knowledge of the real value, organizes sales and influences customers to reach them to buy or purchase as much of the product-service complex as possible using the company's least resources. We might ask the question: in comparison, what is online marketing? Is it a completely new approach or is it just a traditional procedure with new tools (see the articles: 'future is here' [3] or 'online marketing in the age of industry 4.0' [4])? Hossain and Rahman [5] quite simply interpret the activities related to the aforementioned as a process of implementing marketing activities over the Internet. In his work, Fehér [6] has concluded that the online model does not differ significantly from the traditional model of Kotler [7] because the steps of the processes taking place in different media is more or less the same. These authors were still thinking about the five-step model, which can be characterized by the fact that it is the customer who makes the effort and the decision and purchase are essentially the same (see: problem recognition-search-evaluation of alternatives-decision-purchase). Fehér [6] notes that consumer opinion also plays a key role in post-purchase behavior. Kozák et al. (2020) specified and demonstrated an integrated model, where the popular lean approach was developed towards an economic lean method on a supply chain level [8].

A few decades ago a constant feature of marketing has been a "platform type" like a supplying surface, meaning that the focus of its efforts was to provide a kind of interface for the presentation on "offer", as early online solutions were electronic but had only passive appearance characteristics. Obviously, the Internet is suitable for supporting each level of the five-step model with different online tools, thus helping the customer and the purchase process [9], and the consumer may buy online and offline or in a parallel way as well [10].

In the next decade, we will see how mobile or e-commerce will change the traditional models of marketing and even our entire lives, as the impact of customers moves upwards in the model step by step and becomes seriously involved in every step not just in postpurchase behavior (see: review for mobile commerce research and applications [11] and changes in marketing models and motivation causes [12-16]).

Today, however, the Internet is not just a visual interface, it is a lot more active, flexible and dynamic. In addition to the abundance of former economic goods, consumers have also become much more demanding and conscious, it is just enough to offer. Nowadays demand providers need to be much more proactive, and our technology also allows it with all kinds of automated and artificial intelligence systems. On the basis of all this, we do not agree with the above authors and draw attention to the changed differences of online solutions and channels. The attitudes of consumers in online space are constantly changing, the digital content is visited as 'attentively' as possible [17-19], they are not driven towards by pre-planned direction, and they are not interested in traditional geographical or other market boundaries. They have become much more interactive in communication, searching information to their questions in a given time and place as they like and devoting much less time to certain transactions. From a previous passive consumer role, they have changed to a much more active role, which also forces service providers to be proactive. Because this issue appears all the more crucial for corporate strategies since attracting and retaining human capital is a key factor in competitiveness, companies should adapt their marketing strategies [20]. In simple words, strategic consumers make purchase decisions based on the information available and might delay their purchase if it does not maximize their utility [21]. They also turn to value-added information, providing preliminary data for more accurate planning, which represents a new approach for proactivity. Meanwhile, the past decade has witnessed huge changes in the field of information technology and the mobile trend of e-commerce, which can be considered as m-commerce (MC), is a typical 
example of it. Any transaction 'conducted through a variety of mobile equipment over a wireless telecommunication network' can be considered as MC [22-25] In our approach, we will use m-commerce as a part of the e-commerce [11], with a set of specificity and a series of media platforms with their own characteristics and their own media users.

In our current society, the Internet is playing an intensive role in collecting information and influencing customer decisions [26], which is also reinforced by new models such as Weinberg's [27] consumer and shopping process model in both traditional and online space. In these models more and more frequently appears such completely new media types like social network platforms with constantly changing, new methods. (e.g., Facebook, a Google+, Twitter, LinkedIn). Furthermore, it makes new fields for an online presence that enables a two-way communication channel between the company and its suppliers or its customers [28].

It is important for any business maker today to understand that it is unrealistic without useing these applications, especially in case of a new and unique product or if we want to interact with the targeted audience. As there is now a wide variety of online presence, there is a huge increase in the demand for scientific works that analyze or classifies these possibilities. In the next subsection, we review the main differences between traditional commerce and e-commerce.

\subsection{Changes in Sales Methods from E-Commerce to M-Commerce}

The opportunities offered by online media are not only popular because it is fashionable, but also because it gives new methods to marketing or logistics professionals. We have to gain new access to innovative solutions and applications in many areas. Therefore, the aim of this section is to provide a theoretical framework for obtaining the main differences as a model that can help us to design more effective strategies. We can apply innovative developments to more accurately analyze user needs, more accurately explore the dimensions of consumer value, reduce value gaps, do a more accurate and representative in-depth research of the target group, make extensive marketing communication and promotion techniques, artificial intelligence and BI systems for dynamic pricing, most effective promotion planning and measuring, we may be able to assemble and offer innovative product and service combinations that are much more intensively customized, and finally with the help of these providers can proactively recruit a bigger group of potential customers. These new trends could be more powerful than anything the Internet has offered before. For example mobile telephony offers a potential platform for unprecedented penetration of the Internet and services such as m-commerce [25].

Today's major trends and global impacts like the coronavirus disease 2019 (COVID19) pandemic also point out that it is no longer possible to approach merely on economic basis (cost/benefit principle), because both the acceleration of cycles, sustainability issues [29,30] and of course the unpredictability of people support the need for entirely new approaches to process management. In addition to the flow of materials, the flow of information must also be analyzed and modeled on a qualitative and quantitative basis.

The organization of social networks (Facebook) and activity-based (adWords) relationships, or block-chain-based communication, creates different structures compared to traditional models, in value and supply chains that are still organized on conventional relationships. For example, international approaches are very often needed locally. At the level of chains and networks, more complex issues arise than before, which can be developed in a concept that requires the synergy of marketing and logistics. Regarding social networks, for example, Weinberg [31] suggests classifying the following six categories:

1. Social networking. The focus is to reach customers as well as ensuring that interest is maintained while creating relevant contents. Facebook and LinkedIn, for example, are suitable for reaching different audiences.

2. Social knowledge. These are information service sites like Yahoo, Google! They provide answers, help users while also influencing consumers. Wikipedia is similarly suited to influencing society, although the options are much narrower. 
3. Social sharing. These are social bookmarks that allow you to quickly share and spread information, mostly with the help of interesting contents.

4. Social news. It draws attention to a new way of being informed, from which classic roles are also changing (information collecting, share, reader etc.).

5. Social streaming. Rich content that achieves quick effects through instant responses, commenting, and sharing (Podcasting).

6. Company user-generated content and community. In this regard, it is possible for companies, organizations to create independent contents corresponding their own image. Creating a customer community, creating brand loyalty, direct customer contacts can be the goal.

One can obtain more information in a matter of moments in the 21st century than how much information of earlier eras could be combined. Despite of the influence of vast amount of information and new technical possibilities on user purchase intention, there is a lack of a valuable set of factors to evaluate the level of this intention nowadays [32]. The information explosion is now taking place not only in society and science, but even among machines (see Big Data and IoT). Data science is one of the fast-growing disciplines of our time, dealing with processing and utilization of large amounts of rapidly changing data, with the help of artificial intelligence (AI). Online e-commerce is expanding at a rate that it is expected to exceed traditional sales channels. The new e-marketplaces are also spreading by such a traditional markets like agricultural machines or inputs [33]. Acoustic and visual recognition systems simplify the connection between users and the Internet day by day. Augmented reality and virtual reality also implement new levels of perception and allow a better combination of reality and cyber world. The digital boom offers new solutions and opportunities in many areas of life, as well as dangers, which is especially true for the world of e-commerce.

Without aiming to give an lengthy list, let us highlight some of the trends, which are currently in the crossfire of debates.

- online media is extremely suitable for the application of content marketing techniques, but their impact and learning curve work differently platform by platform [1];

- the communication channels and the communication itself have their segments, not only the consumer market, but also the different groups are interested in different contents (however, this requires getting to know them first) $[34,35]$;

- video and podcast content is becoming more popular instead of textual information, partly due to communication degradation, partly due to denser stimulus and information compression, anyone is now able to produce cost-effective videos [35] and YouTube is the third most visited site after Facebook and Google;

- the combination of different media is also a striking phenomenon, which is expected to mutually reinforce each other's short-term image, sound and online content, for example, images in most of the cases can amplify the message [36]-a, and in order to achieve stronger marketing, each platform can also be combined [36]-b;

- bloggers and influencers are able to influence the opinions of their big mass of followers with their own view points and unique appearances [36]-c;

- the importance of marketing automation is rapidly growing year by year, as the diversified activity involves a lot of resources, these duties take over daily tasks like communication, maintaining of contacts, sending e-mail, invoicing, payment [37], Business Intelligence-based demand assessment or offer making and pricing have grate novelty, and the significance of sales funnel is increasing, which goes through the product pyramid [38];

- chatbots are a separate category, which are intelligent robots that can even communicate and take over certain repetitive information handling tasks [39];

- in addition to SEM and SEO (search engine marketing, search engine optimization) [40], Google Ads (adWords) is becoming increasingly important where targeted and re-targeted ads are possible on search and display networks while the focus will be shifted from previous appearance concepts to click-through rate (ctr) method; 
- in addition to search engine marketing and search engine optimization (SEM, SEO), automated information collection and profiling is also being strengthened which in some cases (in case of large service companies) are on the borders on the framework of legality;

- Google Analytics is a legal and accepted option for monitoring user activity which allows statistical analysis and activity tracking of web content from several perspectives [41];

- the importance and effectiveness of direct mails are declining [42].

In the 21st century value (and supply) chains, the buyer can already decide for themselves how and where to get or buy the product, they have far more options than ever before. In this case, the buyer can consider based on several criteria and choose the solution most suitable and most useful for him or her. For example, e-marketplaces in agriculture should ultimately reduce the cost of the exchange of goods [43,44]. Finally, we summarize the similarities and differences between e-commerce and traditional commerce, highlighting the need for changed tasks (see: Table 1).

Table 1. Similarities/differences between e- or m-commerce and traditional commerce.

- $\quad$ the product (product) is the same or similar (essentially the same) regardless of the method of purchase

- $\quad$ product quality and product utility value are the same, independent from the method of acquisition (or transaction)

- the price (price) is the same or maybe a bit cheaper in case of online, compared to the actual store or point of sale

- the payment is the same, in both cases we can pay in cash, by credit card or by bank transfer

- $\quad$ the offer (assortment) is the same or maybe larger in case of online, it is independent from the method of the transaction (except for digital technical problems in some places)

- $\quad$ the possession utility value, there is no significant difference in terms of possession value, the product can transfer with a purchase transaction
- the difference is the (place-marketing channel) of the product and the place utility value which is big because in the traditional way we only reach the product at the store/dealer, while in the online case the transaction can take place anywhere.

- availability of the product in the channel (place) and the time utility value; there is a big difference because in the traditional way we can only access the product during the service hours (opening hours), while in the online case the transaction can take place at any time.

- transport costs; there is a big difference in this case, because in traditional trade the transport costs are belonged to the buyer in relation to the location and the buyer (travel costs) or agreed by parity, but in the online case they are belonged to the provider or it may be passed onto the buyer (shipping cost).

- purchasing convenience; there is a big difference in terms of purchasing, because convenience is an important factor in customer service quality.

- $\quad$ assortment and reliability; there is a big difference, because not only can we choose from the range of assortments of given service provider, but we can also easily compare to different offers of other competitors and choose from offers of replacement product manufacturers (more competition).

- $\quad$ possession utility value; there is a significant difference in the marketing part of the possession utility value, because the "more live" relationship in traditional commerce could mean better customization of the product, that is why the customer service level could be higher and customer satisfaction is improved.

- time utility value with additional time expenditure there is a big difference, because in the traditional case we have to take into account the travel time or the delivery time with "internal" organization, while in the case of online purchase we have to take into account the delivery time with "external" and independent characteristics that mean we have (less influence and occasional less customer satisfaction). 
Table 1. Cont.

- $\quad$ lack of testing and physical detection, the big difference is against an online purchase (which is related to customer security utility value coupled with financial and payment risk or uncertainty).

- $\quad$ personal selling is also against online e-commerce, which is also closely linked to customer service quality and customer satisfaction (email and phone).

- regular or unique purchases must be separate, usually online platform are benefit to use, especially in case for standard regular purchase.

- advantages and disadvantages of geographical boundaries vanish, often national borders, and attraction zones also disappear, which requires different organization (this leads to gradient or scaling problems).

\subsection{Online Sales Data (E-Commerce)}

With the boom of smart devices and mobile technology, e-commerce has also become increasingly popular. Thanks to the development of infrastructure and the growth of customer confidence, 'web shops' are realizing more sales turnover worldwide. Although growth is slowing, online sales worldwide reached $\$ 3.535$ trillion in 2019, with annual growth of nearly $20.7 \%$. Experts predict $18.1 \%$ of total turnover by 2021 viathe electronic channel. For certain products, e.g., in the case of software electronic sales have already outperformed the traditional channel (Apple Store, Play Store, Amazon-Media). According to an Ecommerce Global survey, Asia will have the highest turnover in 2019 with $\$ 1.935$ trillion. In second and third place were North America with $\$ 587$ billion and Europe with far above $\$ 500$ billion in e-commerce [45]. Alibaba Group Holding overtook Amazon in 2017 in the B2C market and also plays a big role in leading Asia to the forefront [46]. However, the gap between the western and eastern parts of Europe, to which our country belongs, is huge. Western Europe accounts for $68 \%$ of the volume, while Central and Eastern Europe accounts for only 11\%. The reason for lagging behind are both infrastructural disadvantage and a trust disadvantage but it also means an opportunity, EuroCommerce [47]. In 2019, the annual online retail turnover of Hungary reached 781 billion HUF, growth of $16 \%$, GKI [48] together with the turnover to abroad is well over 1000 billion. In 2020, annual online turnover has reached 950 billion HUF (above a growth rate of $21 \%$ ), due to the accelerating effect of COVID-19, although the average customer value is lower, purchase is more frequent [49]. Similar effects were observed in many countries [50-52].

According to a survey of webshop experts [53], the attendance and conversion rate of Hungarian web-shops is directly proportional to the age of the web-shop. A web store that has been operating for five years can have up to 10 times the traffic per day as a 1-year-old. Currently, the most popular marketing tools are social media and Facebook advertising $(72-70 \%)$, but SEO (68\%), newsletter (55\%), Google Ads (54\%) and coupon shopping also play a major role (42\%). In terms of efficiency, operators are most satisfied with SEO, Google Ads, social media and 'remarketing'; $45 \%$ of those surveyed do not send any newsletter to their users, while $88 \%$ of online stores have their own Facebook page and $36 \%$ have their own blog. The area for most improvement, according to $66 \%$ of respondents, is (online) marketing, which proves that the topic is crucial [48].

\section{Methodology}

According to our basic concept, there is a great need for more in-depth research on online sales methods, since for businesses, an online presence not only recommended but also almost necessary to strengthen and sped up the traditional channels. The aim of our 
primary research was to identify Hungarian online consumer habits and future trends in order to formulate strategic proposals for companies. The survey was conducted in the form of an online questionnaire in Google Forms, between 6-14 November 2018 before the distorting effect of COVID-19. Data were recorded and analyzed using IBM SPSS and Microsoft Excel. Due to the number of participants and the strong relation between the contact network and personal relationship, the results are not representative they are only suitable for measuring trends. The analysis of answer list-type questions was performed using word cloud and statistical methods. We assume that the Hungarian context data may be considered relevant for all Central and Eastern European countries and in all markets in which the online channels, dynamically evolving the same as in Hungary (see also the rapid growth (18\%-20\% annually) of e-commerce in Hungary [54] and e-commerce in Hungary is in boom phase, or penetration is rapidly increasing [55].) In our methodology we conducted a survey about consumer habits and were able to identify four clear customer cluster categories using K-Central clusters. To set up the clusters, we used six descriptive variables that were established and based on previous studies [56] and in-depth interviews. Respondents were grouped by age, income, use of social network, willingness to click on ads, use of chat bots, and willingness to view YouTube ads in full. The first two criteria were traditional demographic segmentation variables $[23,56]$ and the other four can be considered as typical user behavior characteristics of usage. In the analysis, with these criteria we made an effort to create so few a clear groups that allows the results to be generalized. Some iterations were used on variables in a subjective way to obtain the appropriate clusters and discriminant analyses were used to validate them. The number of clusters was determined empirically in four groups because the differences between the five groups were less significant and the groups were more difficult to interpret. In the last step, we combined the experienced groups with the main specificity categories of e-commerce to gain a two-dimensional strategic matrix with the most obvious activities.

\section{Demographics}

The sample size is 153 people $(n=153)$ participated in the research; $54 \%$ are women and $46 \%$ are men completed the online questionnaire. 6 age groups were classified, from 13 to $65+$ years of age (See Figure 1 ).

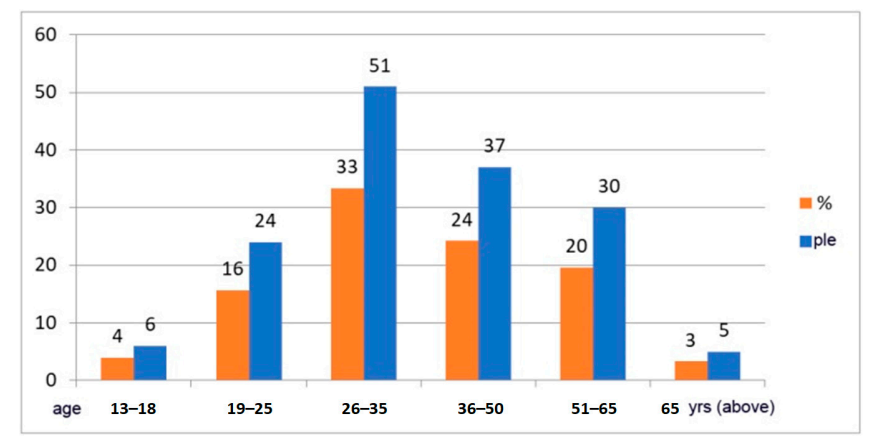

Figure 1. Age distribution. Source: own research, 2018.

As we can see, the highest proportion of 26- to 35-year-olds was represented in the survey by $33 \%$. Almost half of the respondents came from the 36-65 age group. The proportion of respondents under the age of 25 is lower than $16 \%$, and within this the incidence of those under the age of 18 is only $4 \%$. The distribution according to the type of settlement can be said to be even. Most of them (39\%) filled in the survey at the county seat, $27 \%$ in the capital, $29 \%$ in the other cities, and 5\% in villages (See Figure 2).

Comparing the known demographic data with the national one, it can be stated that the random sampling did not bring representativeness. Jász-Nagykun-Szolnok county and the 25-36 age group were over-represented in our survey. 


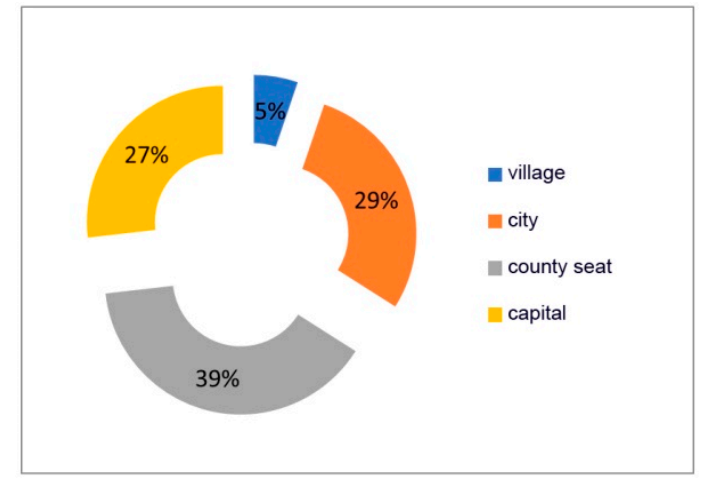

Figure 2. Type of residence. Source: own research, 2018.

\section{Results}

Respondents were grouped according to six criteria using the K-central cluster procedure. The grouping was based on age and income, use of social networking sites, willingness to click on ads, use of chat bots, and viewing of YouTube ads. During the analysis, 4 clear clusters were formed, and their characteristics can be seen in the table below (See Table 2). One of the main problems of the K-central method is the sensitivity to the order of the cases, so we prepared some alternative sequences and accepted the result in which the given clusters could be interpreted empirically and the clusters were sufficient in the number of cases (see also solutions for K-center problem [57].)

Table 2. Characteristics of clusters.

\begin{tabular}{|c|c|c|c|c|}
\hline Variables & \multicolumn{4}{|c|}{ Clusters } \\
\hline What is Your Age? & Age $36-50$ & Age 26-35 & Age 19-25 & Age $36-50$ \\
\hline $\begin{array}{c}\text { How much is your monthly income? (Net) } \\
\text { HUF }\end{array}$ & $100-150$ & $150-200$ & student & $150-200$ \\
\hline $\begin{array}{l}\text { Do you use social networks to search for com- } \\
\text { panies or products? }\end{array}$ & $n i 0$ & yes & yes & yes \\
\hline Do you click on these ads? & no & no & no & yes \\
\hline $\begin{array}{c}\text { Have you ever used a chat window on web- } \\
\text { sites? }\end{array}$ & no & yes & yes & no \\
\hline $\begin{array}{c}\text { Do you watch these commercials all the way } \\
\text { through? }\end{array}$ & rarely & never & never & rarely \\
\hline
\end{tabular}

Cluster Analysis

The members of the first cluster ('buying less') are between 35 and 50 years of age, with a salary of 100,000-150,000 HUF. This group is mainly interested in the content of their friends on social media, they are not looking for company content, they are not receptive to marketing content, they do not typically click on advertisements, they do not use a chat window for information. Ads that appear before YouTube videos are rarely viewed.

The members of the second cluster ('young conscious people') are between 26 and 35, whose earnings range from 150,000 to 200,000 HUF. They prefer to search for companies on social media, but they do not like to click on ads that appear in the search engine. The chat service has typically been used before, but YouTube ads are skipped as soon as possible.

The members of the third cluster ('today's youth') are between 19 and 25 years of age. Since they are typically still studying, they usually have no earnings. They like to search for businesses, use chat on social networks, but they do not like Google ads either, and they skip YouTube ads as soon as they can. 
The members of the fourth group ('prudent users') are in the age group 36-50. Their earnings range from 150,000 to 200,000 forints. In addition to viewing the content of their friends, they are also happy to search for companies. They are happy to click on Google ads because they are more likely to find them more reliable. It can be said of them that they have never used a chat window and YouTube ads are also rarely watched.

Table 3 of ANOVA (analysis of variance) shows that the indications of the variables involved in the cluster analysis are appropriate, as the significance levels of the given criteria are close to zero. From the performed discriminant analysis, we can see that $98.2 \%$ of the respondents almost perfectly fit into the four cluster groups (See: in Table 4).

Table 3. Analysis of variance (ANOVA) table.

\begin{tabular}{r|cc}
\hline & F-Pointer & Significance \\
\hline What is your age? & 68.220 & 0.000 \\
\hline How much is your monthly income? (Net) HUF & 143.961 & 0.000 \\
Do you use social networks to search for companies or products? & 2592 & 0.055 \\
Do you click on these ads? & 36.474 & 0.000 \\
Have you ever used a chat window on websites? & 9006 & 0.000 \\
\hline Do you watch these commercials all the way through? & 10.642 & 0.000 \\
\hline
\end{tabular}

Table 4. Discriminant analysis for defined clusters.

\begin{tabular}{ccccccc}
\hline \multirow{2}{*}{ K-Central Cluster } & \multicolumn{5}{c}{ Suggested Group Assignment } & Total \\
\hline \multirow{3}{*}{ ple } & $\mathbf{1}$ & $\mathbf{2}$ & $\mathbf{3}$ & $\mathbf{4}$ & 44 \\
& 1 & 44 & 0 & 0 & 0 & 56 \\
& 2 & 1 & 54 & 0 & 1 & 19 \\
& 3 & 0 & 0 & 19 & 0 & 28 \\
\hline & 4 & 1 & 0 & 0 & 27 & 100.0 \\
& 1 & 100.0 & 0.0 & 0.0 & 0.0 & 100.0 \\
& 2 & 1.8 & 96.4 & 0.0 & 1.8 & 100.0 \\
& 3 & 0.0 & 0.0 & 100.0 & 0.0 & 100.0 \\
\hline
\end{tabular}

\section{Conclusions and Recommendations}

We can also state from our data that we can distinguish separated groups according to several criteria within consumer groups or consumer segments, according to how they relate to online technology. This phenomenon draws attention to the fact that it is very practical to segment not only according to the consumption habits, but also according to the media channel [1], if we want to carry out effective and economical marketing communication or activity. Our results have been linked to other studies such as the importance of engagement with the social media platforms [1] but we have made an addition that is customer-dependent 'how'. In our examination we successfully applied the six descriptive variables defined from typical user aspects to separate clusters. The implications confirmed are presented in Table 4, showing strong relation.

The shifts in the development of culture and technical background should be taken into account when offering and promoting the new products and services more effective [58]. Based on all this, we elaborate a model that formulates recommendations for the previously described e-commerce differences and the traits of the established cluster groups (see: Table 5). In the fifth table, we combined the results of the first table with the e-commerce specificity categories with the customers' profiles and obtained a twodimensional strategic action matrix with target programming. This table shows in which 
combination, which targeting methods or activities are recommended for marketing professionals and advertisers to use. With all of these you can more easily judge whether to use a particular marketing tool or content feature if you want to target the members of that particular cluster, taking into account the differences.

Table 5. Differences of e-commerce and consumer habits according to the group of 4 clusters combination marketing strategic model.

\begin{tabular}{|c|c|c|c|c|}
\hline & 1. Buying Less & $\begin{array}{l}\text { 2. Young Conscious } \\
\text { People }\end{array}$ & 3. Today's Youth & 4. Prudent Users \\
\hline difference type & $\begin{array}{l}\text { age: } 35-50 \\
\text { money: } 100-150 \\
\text { FaceBook use: no } \\
\text { click-through: no } \\
\text { chat: no } \\
\text { YouTube: rarely }\end{array}$ & $\begin{array}{c}\text { age: } 26-35 \\
\text { money: } 150-200 \\
\text { FaceBook use: yes } \\
\text { click-through: no } \\
\text { chat: yes } \\
\text { YouTube: never }\end{array}$ & $\begin{array}{l}\text { age: } 19-25 \\
\text { money: no } \\
\text { FaceBook use:yes } \\
\text { click-through: no } \\
\text { chat: yes } \\
\text { YouTube: never }\end{array}$ & $\begin{array}{c}\text { age: } 36-50 \\
\text { money: } 150-200 \\
\text { FaceBook use: yes } \\
\text { click-through: yes } \\
\text { chat: no } \\
\text { YouTube: rarely }\end{array}$ \\
\hline $\begin{array}{l}\text { product channel or } \\
\text { place utility value } \\
\text { difference in product } \\
\text { and transaction process: } \\
\text { available anywhere }\end{array}$ & $\begin{array}{l}\text { purchasing } \\
\text { convenience, } \\
\text { argument to be } \\
\text { emphasized }\end{array}$ & $\begin{array}{l}\text { smart-app, } \\
\text { application } \\
\text { development }\end{array}$ & $\begin{array}{c}\text { smart app, } \\
\text { application } \\
\text { development }+ \text { trend } \\
\text { and fashion influence }\end{array}$ & $\begin{array}{c}\text { purchasing } \\
\text { convenience, argument } \\
\text { to be emphasized (it } \\
\text { has value) respond to } \\
\text { well-placed clicks } \\
\text { (social share and media } \\
\text { combinations, Google } \\
\text { Ads) }\end{array}$ \\
\hline $\begin{array}{l}\text { place, time utility } \\
\text { value difference } \\
\text { between product and } \\
\text { transaction process: } \\
\text { is available at any time }\end{array}$ & $\begin{array}{c}\text { online order discount } \\
\text { (when the shops are } \\
\text { closed) }\end{array}$ & $\begin{array}{l}\text { smart-app, } \\
\text { application } \\
\text { development }\end{array}$ & $\begin{array}{c}\text { smart-app, } \\
\text { application } \\
\text { development }+ \text { trend } \\
\text { and fashion influence }\end{array}$ & $\begin{array}{c}\text { purchasing } \\
\text { convenience, argument, } \\
\text { to be emphasized (it } \\
\text { has value) respond to } \\
\text { well-placed clicks (s. } \\
\text { share and media } \\
\text { combinations, Google } \\
\text { Ads) }\end{array}$ \\
\hline $\begin{array}{l}\text { transport costs are } \\
\text { borne by the service } \\
\text { provider or can be } \\
\text { passed onto the buyer }\end{array}$ & $\begin{array}{c}\text { do not use an } \\
\text { expensive method! } \\
\text { (cannot shift or pass) }\end{array}$ & $\begin{array}{c}\text { cost is } \\
\text { transferable, } \\
\text { traceability, flexibility, } \\
\text { phone connection } \\
\text { required }\end{array}$ & cost is transferable & $\begin{array}{l}\text { cost is transferable, } \\
\text { traceability, } \\
\text { flexibility, } \\
\text { phone connection } \\
\text { required }\end{array}$ \\
\hline $\begin{array}{l}\text { purchasing } \\
\text { convenience } \\
\text { higher }\end{array}$ & $\begin{array}{c}\text { purchasing } \\
\text { convenience, argument } \\
\text { to be emphasized }\end{array}$ & $\begin{array}{c}\text { providing } \\
\text { flexibility benefits }\end{array}$ & simplicity is required & $\begin{array}{c}\text { purchasing } \\
\text { convenience, argument } \\
\text { to be emphasized (it } \\
\text { has value) }\end{array}$ \\
\hline $\begin{array}{l}\text { assortment and } \\
\text { reliability } \\
\text { more alternatives }\end{array}$ & $\begin{array}{l}\text { they not react to it, only } \\
\text { wasting money }\end{array}$ & $\begin{array}{l}\text { they react to it, } \\
\text { organised information } \\
\text { suitable for them, } \\
\text { chatbot works }\end{array}$ & $\begin{array}{l}\text { chatbot, } \\
\text { product mix }\end{array}$ & $\begin{array}{l}\text { image of the company } \\
\text { influences the purchase, } \\
\text { content marketing, } \\
\text { more information }\end{array}$ \\
\hline $\begin{array}{l}\text { different possession } \\
\text { utility value 'not so } \\
\text { living relationship' } \\
\text { is harder to customize }\end{array}$ & $\begin{array}{l}\text { make video from } \\
\text { flexibility of usage, } \\
\text { YouTube, Facebook }\end{array}$ & $\begin{array}{c}\text { customizable offers, } \\
\text { product, and service } \\
\text { options are interested } \\
\text { in, } \\
\text { Chatbot, FaceBook (FB), } \\
\text { Search Engine } \\
\text { Optimalisation (SEO) } \\
\text { demand detection, }\end{array}$ & $\begin{array}{l}\text { customization is not } \\
\text { necessary } \\
\text { (few options enough) }\end{array}$ & $\begin{array}{l}\text { Google Ads, Google } \\
\text { Analytics (activity } \\
\text { monitoring), } \\
\text { BI, Artificial } \\
\text { intelligence, } \\
\text { product, and service } \\
\text { options are interested } \\
\text { in, Chatbot, FB, SEO } \\
\text { demand detection }\end{array}$ \\
\hline
\end{tabular}


Table 5. Cont.

\begin{tabular}{|c|c|c|c|c|}
\hline & 1. Buying Less & $\begin{array}{l}\text { 2. Young Conscious } \\
\text { People }\end{array}$ & 3. Today's Youth & 4. Prudent Users \\
\hline $\begin{array}{l}\text { higher time utility } \\
\text { value, } \\
\text { but 'external'- } \\
\text { independent } \\
\text { organisation of } \\
\text { transport, customer has } \\
\text { less influence }\end{array}$ & $\begin{array}{l}\text { very cheap, efficient } \\
\text { logistics, such as pick } \\
\text { pack points, or } \\
\text { personal pick up }\end{array}$ & $\begin{array}{l}\text { traceability, flexibility, } \\
\text { phone connection } \\
\text { required, } \\
\text { delivery company }\end{array}$ & $\begin{array}{l}\text { speed, simplicity, } \\
\text { delivery company }\end{array}$ & $\begin{array}{l}\text { traceability, flexibility, } \\
\text { phone contact required, } \\
\text { delivery company, } \\
\text { personal pick up }\end{array}$ \\
\hline $\begin{array}{l}\text { lack of testing and } \\
\text { physical detection } \\
\text { (less } \\
\text { security utility value) }\end{array}$ & $\begin{array}{l}\text { only personal reference } \\
\text { is recommended }\end{array}$ & $\begin{array}{l}\text { AR-VR options, } \\
\text { enhanced security } \\
\text { utility, reference, } \\
\text { assessment, influencer, } \\
\text { product return } \\
\text { (or send back) }\end{array}$ & $\begin{array}{l}\text { AR-VR options, } \\
\text { enhanced security } \\
\text { utility, reference, } \\
\text { assessment, influencer, } \\
\text { product return }\end{array}$ & $\begin{array}{l}\text { AR-VR options, } \\
\text { enhanced security } \\
\text { utility, reference, } \\
\text { assessment, influencer, } \\
\text { product return }\end{array}$ \\
\hline $\begin{array}{l}\text { less personal contact } \\
\text { on selling or purchase }\end{array}$ & $\begin{array}{l}\text { this is not a problem, } \\
\text { they respond to } \\
\text { traditional marketing } \\
\text { tools: e.g., direct mail }\end{array}$ & $\begin{array}{l}\text { content marketing, } \\
\text { they respond to } \\
\text { segmented } \\
\text { communication, } \\
\text { blogger, influencer } \\
\text { worth it, } \\
\text { but they do not like the } \\
\text { obvious influence, } \\
\text { do not use direct mail }\end{array}$ & $\begin{array}{l}\text { YouTube entertainment } \\
\text { covert advertising, } \\
\text { content marketing, } \\
\text { brand learning, } \\
\text { influencing, FB, } \\
\text { influencer, } \\
\text { use direct promotion }\end{array}$ & $\begin{array}{c}\text { automated information } \\
\text { gathering and profiling, } \\
\text { sales funnel, combining } \\
\text { media } \\
\text { YouTube advertising- } \\
\text { click-through, online } \\
\text { advertising has the } \\
\text { most effect } \\
\text { Google and FB ads }\end{array}$ \\
\hline $\begin{array}{l}\text { regular or individual } \\
\text { purchases are different }\end{array}$ & $\begin{array}{l}\text { unique FB offers, } \\
\text { discount videos }\end{array}$ & $\begin{array}{l}\text { willing to buy regularly, } \\
\text { it is worth to use } \\
\text { invitation into } \\
\text { customer communities } \\
\text { and marketing } \\
\text { automation }\end{array}$ & $\begin{array}{l}\text { willing to buy regularly } \\
\text { (not he or she pay), } \\
\text { invitation into } \\
\text { customer communities } \\
\text { and marketing } \\
\text { automation }\end{array}$ & $\begin{array}{l}\text { unique purchase and } \\
\text { regular purchase are } \\
\text { both interested in }\end{array}$ \\
\hline $\begin{array}{l}\text { lack of advantages } \\
\text { and disadvantages of } \\
\text { geographical zones }\end{array}$ & $\begin{array}{l}\text { limited access because } \\
\text { unlimited is not worth } \\
\text { it }\end{array}$ & $\begin{array}{l}\text { he or she prefers } \\
\text { unlimited access }\end{array}$ & $\begin{array}{l}\text { he or she prefers } \\
\text { unlimited access }\end{array}$ & $\begin{array}{l}\text { he or she prefers } \\
\text { unlimited access }\end{array}$ \\
\hline
\end{tabular}

We recommend using the model above, or re-examining and refining it in your own industry, for any business that uses online technology but currently is driven by an idea or fashion, with more or less success. In our opinion, a lot of unnecessary energy and resources can be saved with a more targeted marketing activity. This easy-to-use theoretical framework can be seen as a day-to-day practical contribution for managers, and in theory we have successfully created a model in which the specifics of the social media platforms and the user profile together influence the desired strategic actions. The limitation of the model is that these recommendations are too general for different electronic devices and platforms and may require some revision in different industries. At a later stage, it would be a logical research perspective how these factors correspond to each other after COVID-19 or to conduct a more in-depth study of how these actions contribute to success.

Summary: In conclusion, the conscious creation of customer communities and proactive behaviour and targeted communication towards them can be one of the proven directions of business development. Nowadays the customer demands just customized products and services well as the personalized (or targeted) on time, well-located information, or communication. For now, the technical barriers have been dismantled and there are countless solutions with varying degrees of effectiveness. The task is to get the right information to the potential user through the right information channel. We hope that our study and any other similar research can help you in this process. 
It is warmly advisable to expand the scope of activities of companies that previously used only traditional marketing communication tools and channels into the direction of online content and online customer relations, that is the key to success.

Author Contributions: Conceptualization, B.G. and L.V.; methodology, B.G.; software, Z.M.; validation, Y.B.; formal analysis, Z.M.; investigation, B.G. and Z.M.; resources, B.G. and L.V.; data curation, Z.M.; writing-original draft preparation, B.G.; writing-review and editing, L.V.; visualization, B.G.; supervision, Y.B. and L.V.; project administration, I.V.; All authors have read and agreed to the published version of the manuscript.

Funding: This research received no external funding.

Institutional Review Board Statement: Not applicable.

Informed Consent Statement: Not applicable.

Data Availability Statement: Not applicable.

Conflicts of Interest: The authors declare no conflict of interest.

\section{References}

1. Voorveld, H.A.M.; Van Noort, G.; Muntinga, D.G.; Bronner, F. Engagement with Social Media and Social Media Advertising: The Differentiating Role of Platform Type. J. Advert. 2018, 47, 38-54. [CrossRef]

2. Gamble, J.; Gilmore, A.; McCartan-Quinn, D.; Durkan, P. The Marketing concept in the 21st century: A review of how Marketing has been defined since the 1960s. Mark. Rev. 2011, 11, 227-248. [CrossRef]

3. Schwarzl, S.; Grabowska, M. Online marketing strategies: The future is here. J. Int. Stud. 2015, 8, 187-196. [CrossRef]

4. Hoi, H.T. Attractiveness of Online Marketing in the Age of Industry 4.0. In Proceedings of the 2020 The 6th International Conference on E-Business and Applications, Kuala Lumpur, Malaysia, 25-27 February 2020; Published: ICEBA 2020. pp. 1-4.

5. Hossain, M.S.; Rahman, M.F. Tools of online marketing. Int. J. Sci. Bus. 2017, 1, 1-7. [CrossRef]

6. Fehér, A. Online élelmiszer-vásárlói és -fogyasztói magatartás. In Élelmiszer-Marketing; Szakály, Z., Ed.; Akadémiai Kiadó: Budapest, Hungary, 2017; pp. 108-120.

7. Kotler, P.; Keller, P.K. Marketing Management, 15th ed.; Pearson Education Inc.: Hoboken, NJ, USA, 2016.

8. Kozák, T.; Madleňak, R.; Neszmélyi, G. How the lean management decision influences the transportation cost in the supply chain? Commun. Sci. Lett. Univ. Žilina 2020, 4, 13-19. [CrossRef]

9. Chaffey, D.; Ellis-Chadwick, F.; Mayer, R.; Johnston, K. Internet Marketing: Strategy, Implementation and Practice, 3rd ed.; Financial Times Prentice Hall, Edinburgh Gate: Harlow Essex, UK, 2006.

10. Hahn, J. E-Commerce Site Design, Online Consumer Behavior and Business Value. Ph.D. Thesis, Information and Decision Sciences Carlson School of Management University of Minnesota, Minneapolis, MN, USA, 2002.

11. Ngai, E.; Gunasekaran, A. A review for mobile commerce research and applications. Decis. Support. Syst. 2007, 43, 3-15. [CrossRef]

12. Zhenga, X.; Mena, J.; Yanga, F.; Gongb, X. Understanding impulse buying in mobile commerce: An investigation into hedonic and utilitarian browsing. Int. J. Inf. Manag. 2019, 48, 151-160. [CrossRef]

13. Ghose, A.; Goldfarb, A.; Han, S.P. How Is the Mobile Internet Different? Search Costs and Local Activities. Inf. Syst. Res. 2013, 24, 613-631. [CrossRef]

14. Lee, T.; Park, C.; Jun, J. Two Faces of Mobile Shopping: Self-Efficacy and Impulsivity. Int. J. E-Bus. Res. 2014, 10, 15-32. [CrossRef]

15. Kim, H.-W.; Chan, H.C.; Gupta, S. Value-based Adoption of Mobile Internet: An empirical investigation. Decis. Support. Syst. 2007, 43, 111-126. [CrossRef]

16. Luo, X.; Andrews, M.; Fang, Z.; Phang, C.W. Mobile Targeting. SSRN Electron. J. 2013, 60, 1738-1756. [CrossRef]

17. Janal, S.D. Online Marketing Handbook (Business Technology Series); John Wiley \& Sons: Hoboken, NJ, USA, 1999.

18. Fehér, A. Az online marketing lehetőségei és megítélése a hazai élelmiszergazdaságban. Agrártudományi Közlemények 2014, 58, 77-84.

19. Pakurár, M.; Benedek, S.; Popp, J.; Magda, R.; Oláh, J. Trust or Doubt: Accuracy of Determining Factors for Supply Chain Performance. Pol. J. Manag. Stud. 2019, 19, 283-297. [CrossRef]

20. Mičík, M.; Mičudová, K. Employer Brand Building: Using Social Media and Career Websites to Attract Generation Y. Econ. Sociol. 2018, 11, 171-189. [CrossRef] [PubMed]

21. Victor, V.; Thoppan, J.J.; Fekete-Farkas, M.; Grabara, J. Pricing strategies in the era of digitalisation and the perceived shift in consumer behaviour of youth in Poland. J. Int. Stud. 2019, 12, 74-91. [CrossRef]

22. Liu, Z.; Liu, Z.; Min, Q. The Impact of Mobile TradeManager on Fashion Product Sales: From Usability Perspective. Math. Probl. Eng. 2014, 2014, 1-9. [CrossRef]

23. Yang, K.C. Exploring factors affecting the adoption of mobile commerce in Singapore. Telemat. Inform. 2005, 22, 257-277. [CrossRef] 
24. Balasubraman, S.; Peterson, R.A.; Jarvenpaa, S.L.; Balasubramanian, S. Exploring the Implications of M-Commerce for Markets and Marketing. J. Acad. Mark. Sci. 2002, 30, 348-361. [CrossRef]

25. Barnes, S.J. The mobile commerce value chain: Analysis and future developments. Int. J. Inf. Manag. 2002, 22, 91-108. [CrossRef]

26. Gupta, G.; Miller, M.K.; Darda, M. The key to successful online marketing for an orthodontic practice: Mastering the plan. Semin. Orthod. 2016, 22, 313-321. [CrossRef]

27. Weinberg, B.D. Reasearch in exploring the online consumer experience. Adv. Consum. Res. J. 2001, 28, $227-232$.

28. Hu, X.; Ocloo, C.E.; Akaba, S.; Worwui-Brown, D. Effects of business to business e-commerce adoption on competitive advantage of small and medium-sized manufacturing enterprises. Econ. Sociol. 2019, 1, 80-99. [CrossRef]

29. Oláh, J.; Kitukutha, N.; Haddad, H.; Pakurár, M.; Máté, D.; Popp, J. Achieving Sustainable E-Commerce in Environmental, Social and Economic Dimensions by Taking Possible Trade-Offs. Sustainability 2018, 11, 89. [CrossRef]

30. Oláh, J.; Aburumman, N.; Popp, J.; Khan, M.A.; Haddad, H.; Kitukutha, N. Impact of Industry 4.0 on Environmental Sustainability. Sustainability 2020, 12, 4674. [CrossRef]

31. Weinberg, T. The New Community Rules: Marketing on the Social Web; John Wiley \& Sons: Hoboken, NJ, USA, $2010 ;$ pp. $28-29$.

32. Roudposhti, V.; Nilashi, M.; Mardani, A.; Streimikiene, D.; Samad, S.; Ibrahim, O. A new model for customer purchase intention in e-commerce recommendation agents. J. Int. Stud. 2018, 11, 237-253. [CrossRef]

33. Késmárki-Gally, S. Application of a modern marketplace in the European agribusiness. Agroecon. Croat. 2015, 1, 41-50. [CrossRef]

34. Vasa, L.; Baranyai, Z.; Kovacs, Z.; Szabó, G.G. Drivers of Trust: Some Experiences from Hungarian Agricultural Cooperatives. J. Int. Food Agribus. Mark. 2014, 26, 286-297. [CrossRef]

35. Dufett, R. The YouTube Marketing Communication Effect on Cognitive, Affective and Behavioural Attitudes among Generation Z Consumers. Sustainability 2020, 5075, 5075. [CrossRef]

36. Tóth, M. Online Marketing; Netkreatív.huLtd. Publishing: Százhalombatta, Hungary, 2012; (a) pp. 173-186, (b) pp. 75-82, (c) pp. 63-68.

37. Tóth, M. Marketing Automatizálás Egyszerüen; Netkreatív.hu Publishing: Százhalombatta, Hungary, 2017 ; pp. 21-32.

38. Szőke, A.; Domán, Z. Online Vevőszerzés Csúcsra Járatva; Nitronet Media Publishing: Budapest, Hungary, 2015 ; pp. 42-46.

39. Balogh, D. Mindent a Messengers Chatbotokról! Available online: https://boommarketing.hu/messenger-chatbotok/mindentmessengeres-chatbotokrol/ (accessed on 11 November 2020).

40. Bányai, E.; Novák, P. Online Üzlet és Marketing; Akadémia Kiadó: Budapest, Hungary, 2011; pp. $188-190$.

41. Geiger, T. Miért Fontos az Analitika?-és Hogyan Szerezz Használható Adatokat a Google Analyticsből? Available online: https:/ / webshark.hu/hirek/google-analytics-hasznalata/ (accessed on 1 November 2020).

42. Benyó, D. E-Mail Marketing; Kreatív Kontroll Publishing: Budapest, Hungary, 2017; pp. 8-18.

43. Késmárki-Gally, S.; Fenyvesi, L.; Takács-György, K. The role of agricultural e-marketplace in public organizations. Optim. Studia Ekon. 2015, 6, 15-26. [CrossRef]

44. Szalka, É.; Tamándl, L.; Kovács, Z.; Pupp, Z. Hatékonyság vizsgálata a mezőgazdasági vállalkozásoknál. Acta Agron. Óváriensis 2020, 1, 123-158.

45. Global E-Commerce 2019. Available online: https://www.emarketer.com/content/global-ecommerce-2019 (accessed on 27 November 2020).

46. Kochkodin, B. Alibaba Tops Amazon to Become the Biggest E-Commerce Company; Bloomberg L.P.: Frankfurt, Germany, 2017. Available online: https: / /www.bloomberg.com/news/articles/2017-10-10/alibaba-tops-amazon-to-become-biggest-e-commercecompany-chart (accessed on 25 October 2018).

47. EuroCommerce. The European Ecommerce Report 2018: Relevant Findings Outlined; EuroCommerce: Brussels, Belgium, 2018. Available online: https:/ / www.eurocommerce.eu/media/159952/2018.07.02\%20-\%20Ecommerce\%20report_annex.pdf (accessed on 23 October 2020).

48. GKI, Economic Forecast for 2020, GKI Economic Research Co, Hungary. Available online: https://www.gki.hu/language/en/ tag/world-economy/ (accessed on 25 October 2018).

49. eNet Új Szintre Léphet a Hazai E-kereskedelem. Available online: https://enet.hu/hirek/uj-szintre-lephet-a-hazai-ekereskedelem/ (accessed on 20 March 2021).

50. Pantelimon, F.-V.; Georgescu, T.M.; Posedaru, B.-S. The Impact of Mobile e-Commerce on GDP: A Comparative Analysis between Romania and Germany and how Covid-19 Influences the e-Commerce Activity Worldwide. Inform. Econ. 2020, $24,27-41$. [CrossRef]

51. Statista. Increases in CPG Demand Due to COVID-19 Outbreak Worldwide March 2020, by Country; Statista GmbH: Hamburg, Germany, 2020. Available online: https:/ / www.statista.com/statistics/1105409/coronavirus-change-in-cpg-purchasesby-countryworldwide/ (accessed on 28 November 2020).

52. Statista. Coronavirus Impact on Online Traffic of Selected Industries Worldwide in Week Ending April 26, 2020; Statista GmbH: Hamburg, Germany, 2020. Available online: https:/ / www.statista.com/statistics/1105486/coronavirus-traffic-impact-industry/ (accessed on 25 November 2020).

53. WebShop Experts. Lezárult a Nagy Webáruház Felmérés 2018. pp. 3-22. Available online: https:/ /www.webshopexperts.hu/ lezarult_a_nagy_webaruhaz_felmeres_2018 (accessed on 14 October 2020).

54. Nagy, S. E-Commerce in Hungary: A Market Analysis, Theory, Methodology, Practice. Theory Methodol. Pract. 2016, 12, 25-32. Available online: https: / / ssrn.com/abstract=2915031 (accessed on 25 November 2020). 
55. Gáti, M.; Simay, A.E. How consumers can understand the role and relevance of social mobile e-commerce. In Tanulmányok a Digitális Marketing, Média és Design Területéről; Corvinus University: Budapest, Hungary, 2019; pp. 9-17. ISBN 978-963-503-798-8.

56. Jayawardhena, C.; Wright, L.T. Consumers online: Intentions, orientations and segmentation. Int. J. Retail. Distrib. Manag. 2007, 35, 515-526. [CrossRef]

57. Garcia-Diaz, J.; Sanchez-Hernandez, J.; Menchaca-Mendez, R.; Menchaca-Mendez, R. When a worse approximation factor gives better performance: A 3-approximation algorithm for the vertex k-center problem. J. Heuristics Springer 2017, 23, 349-366. [CrossRef]

58. Naumova, O.; Bilan, S.; Naumova, M. Luxury consumers' behavior: A cross-cultural aspect. Innov. Mark. 2019, 15, 1-13. [CrossRef] 